\title{
CHILDHOOD EXPERIENCES OF RECIDIVISTS AS PREDICATORS OF CRIMINOGENIC LIFESTYLE
}

\author{
Arkadiusz Urbanek \\ University of Wroclaw, Poland \\ E- mail: aur@pedagogika.uni.wroc.pl
}

\begin{abstract}
The research tackles the issue of the reconstruction of childhood experiences of recidivists. The aim of these reflections is to search for cause and effect relation between socialisation experiences and further criminogenic lifestyle. It is an interdisciplinary work due to the fact that the issue of socialisation, transmission of behaviour patterns and environmental influences reflect scientific domains of psychology, criminology and resocialisation pedagogy. Accomplishing the objective to reconstruct experiences and their relation with subsequent deviant activities a source material from auto-anamnestic interviews was applied. During the research 100 respondents aged 22 to 30 were interviewed. Each of them has already been sentenced repeatedly for criminal offences, serving the punishment of deprivation of liberty. The research was conducted in 2013. In terms of methodology the data analysis concentrated on the qualitative model of structural and reconstruction research, whereas the results were presented within cause-effect matrixes. The construction of each matrix was designed to classify and present common areas of experiences that occurred within biographies of the individual respondents. Therefore, the research, despite its qualitative nature, categorised the socialisation experiences and the predicators of criminogenic lifestyle subject to subgroup classification. The procedure of analysis was dual, i.e. the cause matrixes of 33 random cases were firstly designed, and then applied to replicate the experiences of the rest of the respondents from the group. It allowed not only to distinguish similar experiences but also consolidated the matrixes as tools for further interpretation. The results of research of socialisation experiences and predicators of criminogenic lifestyle are applicable for penitentiary resocialisation practice and psychological support for the prisoners. Moreover, the research results revealed crucial areas of disturbances, such as isolation from the relatives, void of emotional contacts, susceptibility to deviant group influences, or reducing the hierarchy of values to the desires of possession, unfulfilled in their childhood.
\end{abstract}

Key words: childhood, parents - children, pathogenic factors, relations, socialization.

\section{I ntroduction}

Human experiences gained during the process of socialisation draw attention of experts in criminology, psychology as well as resocialisation pedagogy. The significant importance of this process results from its complex nature and its creative function. Emil Durkheim perceived the course of socialisation from a perspective synonymous to upbringing concerning it socially most distinguished process of introducing individuals to the domain of social life (Hurrelmann 1994, p. 15, Toron 2012, p. 15). Such concept of socialisation implied its dualistic dimension with pre- 
dominant role of consolidated system of social functioning, and subsequent process of shaping features of a socialised individual as a result (outcome) of the primary influences. Direct and indirect participation of a child in social systems and structures undoubtedly determines its position in a group, hence the crucial process of creating, or even determining human's fate. The power and quality of childhood socialisation influences is significant in terms of human's position within a society. Therefore, socialization can be of a selective nature with its course implying forecast within the social promotion or degradation. Taking into account sociological or emancipative perspective there are different approaches interpreting the role of socialisation experiences, variably deterministic. Nonetheless, experiences of work with juvenile delinquents or adult offenders prove there is a tight link between the upbringing and further lifestyle. Consolidation of previous experiences implies duplication of the learned pattern of social participation and human's fate with significantly higher percentage of risk behaviour among those from low-income families (Qi, Kaiser 2003, p. 188) and of marginalised social function. Jerzy Modrzewski recognizes such deterministic character of socialisation in the context of a specific social location of a human where negative or positive experiences from childhood assign such person to a given social group (Modrzewski 2007, p. 42). It is worth to emphasise that Harold Garfinkel interprets socialisation in a similar, deterministic manner, stressing its degrading nature due to the fact that early experiences can be sufficiently influential to determine the quality and direction of the course of further stages of entering social life (Garfinkel 1956, pp. 420-424). Following such deterministic approach to socialisation it may be assumed that the predicators of criminogenic lifestyle are distinct as far as childhood experiences are concerned.

Environmental transmission and selective function of socialisation are of paramount importance for the process of consolidating human tendencies to criminogenic behaviour. Hence, recognising socialisation experiences is in the scope of attention as far as behaviour disturbances, social, and criminal diagnosis and therapy are concerned. Recognition of early life experiences reveals subsequent areas of deficiencies and consistently forecasts the style of individual functioning within a society. There is a wide range of theoretical and empirical knowledge concerning this issue, reflecting both the area of deficiencies and the category of protective factors. Taking criminogenic behaviour into account, the key role is played by the analysis of defects originating from the socialisation period and resources neutralising its power. Deterministic nature of negative socialisation experiences of recidivists is emphasised by John Muncie, who claims that increase in criminogenic behaviour and activity within criminal groups emerges around 40 years of age. Consolidated patterns and lifestyle determine social functions, hence neither correctional nor punitive measures can diverse this process. However, as the individuals get older, tendency to risk behaviour is decreasing (Muncie 2004, Rzeplińska 2006, p. 343). Recognising negative socialisation experiences from such perspective is crucial in terms of reconstructing the decisive processes of the offenders. Taking into consideration recidivists, i.e. those lapsing into previous, undesirable code of conduct transgressing law, such analysis reveals great intensity of this behaviour. These are not single episodes, but patterns constituting coherent part of reinforced, criminogenic lifestyle. According to Jan M. Stanik, recidivists undertake risk behaviour on basis of which they set up or evoke series of different criminogenic situations of great risk intensity (Stanik 2007, p. 193). In her works, Emma J. Palmer highlights similar aspect, i.e. the necessity to recognise previously reinforced personality mechanisms that allow to understand the sources of such deeprooted, criminogenic lifestyle (Palmer 2007). Therefore, interpretation of the experiences from the childhood socialisation remains significant in interpreting criminogenic behaviour, thus the presented research constitute an attempt to explore such deterministic role of socialisation. The procedure of empirical analysis searched for given patterns of activity, similarities and differences resulting from socialisation experiences.

Notwithstanding, while interpreting socialisation experiences and further criminogenic lifestyle of the respondents, it was necessary to outline current knowledge concerning the factors determining harmful behaviour and resources that suppress their intensity. The domestic and international literature provides in-depth information tackling disturbances of socialisation processes, hence the analyses of psychological, pedagogical or anthropological approaches reach beyond the objectives of these reflections. Nonetheless, it must be remembered that the context of family 
relations constitutes key spectrum for the interpretations of the socialisation interferences. These aspects are tackled within theoretical analysis, as a description of the own research results also refers to the issue of child-parents relations.

According to Hanna Olechnowicz, child-parents relations convey a specific potential which protects children from deviant behaviour in their adult life. The author claims that during the infancy stage emotional bond between the child and both the mother and the father play a key part. Establishing bonds takes place mainly through child's senses, i.e. the smell, touch, sight, hearing and taste as these constitute complimentary channels of communication with others at this developmental stage. As a result of sustaining emotional closeness the process of shaping empathy is launched, followed by a stable system of feelings and mature "Me" structure (Olechnowicz 1998, p. 9). In adult life, such features become a crucial potential protecting against manifestation of deviant behaviour, concurrently constituting predispositions that are not inborn, but established at the age of 3 on the basis of emotional bonds between the child and own parents (1998, p. 9). Such approach is theoretically and empirically justified as disturbances within higher emotions, in particular inability to experience empathy, have been repeatedly tackled in the context of human tendency to delinquent or criminal offences. Adequately, positive experiences of emotional closeness of a child with own parents are interpreted as correlates of behaviour control. According to Julian Bielecki when a mother has no emotional relation with own child, nor expresses feelings tightening the bonds between, she is incapable of controlling own child's behaviour in other way than by repression (Bielecki 1993, p. 11). Positive relations with parents in the early childhood are significant for the process of shaping human's ability to reciprocate the welfare, hence it constitutes a key potential regulating social life, concurrently playing important part in the process of socialisation. As Robert Trivers claims, the morality of an adult person is founded in the ability to act as an altruist, for altruism is a resource allowing one to suppress egoism. Hence, people need to learn skills to act for the welfare of others, counting on reciprocity of positive experiences (Trivers 1971). The child-parents relations also make up such foundation enabling the process of shaping self-assessment and sensitivity to its maintenance. As far as behaviour regulating mechanisms are concerned, an interesting viewpoint was presented in the 1930s by a German criminologist and lawyer, Hellmuth Mayer, who claimed that a severe punishment does not deter from harmful behaviour due to the fact that the sense of shame functions as a regulator of lawful conduct (Mayer 1932). Nonetheless, it must be remembered that the sense of shame, remorse or guilty conscience is an experience that combines positive self-assessment and effort made to sustain such image. Therefore, when negative socialisation experiences have caused destruction of positive self-assessment, it is more than apparent that the pressure of shame and disapproval of the social surrounding will not protect from deviation.

As far as recidivists' biographies are concerned, the process of socialisation was very often disturbed, hence with regards to the above reflections it may be assumed that at the period of childhood they were not provided with appropriate protective resources. However, the reality seems to be quite different, as the research proves they were equipped with predispositions intensifying their criminogenic behaviours, relating to the acquired specific lifestyle, way of thinking, recognition of own needs and way of their fulfilment. Moreover, specific features of personality were preserved, consolidating permanent determinants of socially harmful behaviours. According to Jan M. Stanik, the personality traits significantly shape criminogenic lifestyle and are far more influential that situational factors experienced by a given person (Kucharewicz 2008, p. 207). In such context, the deterministic nature of the process of socialisation can be interpreted as an implication of experiences locating such human within given social group. In most cases these constitute antagonistic deviant groups as they enable the youth to adapt, despite their aggressive or withdrawn attitude. Deviant groups become in such case a point of reference as they accept the deviants and provide them with opportunities to undertake criminogenic activity.

Concentrating on negative aspects of socialisation experiences of criminals, attention must be drawn to the reconstruction of their relations with parents, as in empirical research the issue of controlling own child during socialisation is of paramount importance. The results of research by Fred Rothbaum, John R. Weisz (1994) and T.M. Achenbach (1991) outlined relations between excessively harsh parental control and the tendency to depressive and passive behaviour among 
adult women and men. It proved that negative aspect of parental control may lead to a situation when a psychological distance between a parent and a child is remained, hence the family relations are grounded in manipulation with the use of psychological separation. Such control limits the development of a child's individuality introducing chronic sense of fear of losing the closeness. These negative socialisation experiences were confirmed and described by Brian B. Barber, Joseph E. Olsen, Shobha C. Shagle (1994) and Arim G. Rübab, Sheila K. Marshall, Jennifer D. Shapka (2003), confronting psychological control with the behavioural one. The research projects revealed that parents do not interfere in child's issues, simultaneously preserving from introduction of sufficient rules and regulations of behaviour. Hence, as a result of insufficient regulators and social norms, the process of socialisation does not provide with adequate mechanisms protecting from socially harmful activities (Urban 2000, p. 166). In terms of parental control, according to German philosopher and lawyer, Günther Jakobs, particular role is played by parents' consequence concerning the act of taking care of their offspring. Hence, it is not the harsh punishment, but consequent reaction to their children's behaviour that equip them with internal mechanisms regulating behaviour (Jakobs 1991).

From the perspective of Polish society at large, the research concerns significant social group, concentrating of the childhood experiences of nowadays recidivists. Nonetheless, their problem of socialisation during childhood implies a wider context of family and social circles. Statistical data published by Polish central prison service indicate that the group of recidivists (men and women) serving sentences in Polish prisons between 2011 and 2012 reached ca. 367000 individuals (http://www.sw.gov.pl/pl/o-sluzbie-wieziennej/statystyka/). Taking into account the fact the most of them were socialised in families, the scope of research on socialisation in the period of childhood is broad. Similarly, if it is taken into consideration that the phenomena of deprivation affect impoverished or marginalised environments due to economic or social reasons, such social group is also of paramount research importance. As the results of macrosocial research in Poland prove, in 2012, the risk group subject to extreme poverty reached $6.7 \%$. It particularly affects these families that experience various life difficulties and economic burdens. The indicated group is also impacted by unemployment, hence if such a family consists of two or more persons without work, the level of extreme poverty risk reaches as high as $32,9 \%$. Poverty concerns mostly those families that bring up four or more children $(26.6 \%)$ contrary to three-children families where $9.7 \%$ are subject to such negative process. Low level of education is another factor that also occurs within the researched group of perpetrators and penitentiary recidivist in particular. The group tackled by extreme poverty embraced those with lowest possible education (junior high school the maximum), however the indicators are definitely lower among those with medium education level (3.4\%) and high one (0,5\%) (http://www.stat.gov.pl/cps/rde/xbcr/gus/ WZ_ubostwo_w_polsce_2012.pdf).

\section{Methodology of Research}

\section{General Background of Research}

The accomplished research was conducted within framework of the structural - reconstruction analysis where key part tackled biographical description of experiences and the interpretation it involved. The reconstruction of the structure and the co-related links between biographical experiences and events were in the scope of interest. It was followed by analysis and secondary reconstruction of the principles of human's conduct and activity. The idea of structural and reconstruction research is grounded in philosophical paradigm of hermeneutics, that is related to the reconstruction of given emotional state and human experiences through which it enables wider, contextual interpretation of the life situation of given individuals. Such approach corresponds with the adopted objectives of conducted research project. The key goal of the analysis of gathered source material was the attempt to present the socialisation situation and experiences in the context of criminogenic lifestyle of the recidivists. Within such range, crucial information was provided by application of auto-anamnestic description, i.e. recalling own experiences from the period of childhood socialisation. Additionally, relations with adults experienced by given individuals dur- 
ing their childhood were also taken into account.

Accomplishing the aim of the research it was necessary to structure the procedure of methodical stages, i.e. data selection and interpretation. It must be remembered that the research aim was no to reveal single, individual or situational variables that remain in correlation with the lifestyle, as reinforcing criminogenic lifestyle does not refer to capturing precise and directly time-related single events. Moreover, the scope of interest did not embrace individual behaviour, but a wider context of the process of experiencing and its convoluted, active dynamism.

Such methodological approach, concentrated on hermeneutical qualitative analysis, is deeply rooted in theory. Taking into consideration the criminal lifestyle, Raymond Gassin promoted its perception applying wide-ranging process of criminogenesis, which is a dynamic, complex, multistage process reaching beyond search for individual variables determining lifestyle (Gassin 2003 p. 9). A similar approach is presented by a Polish criminologist, Stanisław Batawia, who perceived criminogenic factors as co-related circumstances, directly or indirectly favouring deviant behaviour. According to this scholar, etiology of criminogenesis and moral structure of the offenders should be considered genetically, not statistically. Hence, retrospective, qualitative research projects are of great value as they focus on the complexity of social conditions experienced by the offender (Tyszkiewicz 2007, p. 215).

\section{Sample Selection}

Empirical analysis embraced source material consisting of 100 direct interviews of anamnestic nature, carried out with recidivists. Interviews were of diagnostic nature, concentrating on the issues of deficits diagnosis, as well as social and criminogenic forecast accomplished during the period of deprivation of liberty. The group of research focus consisted of recidivists repeatedly sentenced to deprivation of liberty. The category of the offence was irrelevant as the focus was on young people, i.e. 22 to 30 years of age, in order for their childhood experiences to be possibly accessible. It must be remembered, however, that Polish Criminal Executive law does not classify sentenced recidivists before they reach the age of 21 . The analysed empirical material was gathered by a research team in 2013.

The essential research problems were formulated within three questions, i.e. 1. How do the respondents assess their own relations with their closets relatives in their childhood? 2. How did the process of pathogenesis unfold? 3. Which factors accompanied the emergence of permanent criminogenic life style? At this point it is essential to precise adopted meaning and understanding of the terms pathogenesis and criminogenesis. The first term has been defined as a process of reinforcing socially harmful or deviant behaviour, whereas the latter is secondary to the pathological behaviour and refers to frequent, repeatable criminal offences. The difference between these two notions refers to the time category and personal experiences. Since pathogenesis implies negative socialisation experiences, it tackles the issue of a given problem from the childhood, often resulting from negative socialisation. Within this range, first harmful or deviant behaviours were subject to analysis as only in the further consequence they can transform into consolidated mechanisms predominant in a criminogenic lifestyle. Hence, specifying the process of pathogenesis of behaviours throws light on consequent offensive and criminal activities that result from such circumstances. Therefore, reconstruction of both childhood memories from the period of socialisation and related activities reflecting the initial stage of pathogenesis were in the scope of research attention.

\section{Instruments and Procedures}

From the perspective of methodological correctness it is particularly important to precise the issues of reconstructing criminal lifestyle, since - as theoretically implied - the criminogenic lifestyle is a dynamic process, unquestionably connected to socialisation experiences. Therefore, precise procedure of methodical analysis of source material is of paramount importance in order to accomplish the tasks of reconstruction of such style. Hence, comparable matrixes were applied for the purpose of its each-case interpretation. The matrixes allowed to present the experiences of individuals, and in further consequence to search for similarities and differences within such 
personal experiences. Following the concept of hermeneutics research, the matrixes presented a cross-section of experiences and interpretation analysed in a longer time perspective, providing the picture of both experiences, interpretation and hypothetical cause-effect relations between.

For construction of such case-effect networks the induction (generative) approach was applied in order to compare not single events, but wider context of biographical experiences depicted as structures, or even networks of activities, events and emotional states (Milles, Huberman 2000, pp. 158-160). Such methodical approach is well-grounded both in philosophy and methodology. The established concept of research provides the definition of term causality different from those proposed by philosophers such as John Lock or David Hume. In a narrow understanding, the cause-effect relation joints and links given events with the quantifier of time. The cause of events requires some time relation in which one event evokes another. However, in case of interpretation of causality and procedural character of consolidating criminogenic lifestyle such approach is selective, i.e. the research project tackled time only from the retrospective perspective, i.e. general division that some events proceeded some other hypothetical responses to them. On the other hand, concentrating on the cause of events, Andrew Abbot's approach is far more methodologically grounded, as he promoted understanding of causality in a miscellaneous relation as one effect can have various causes, simultaneously evoking consequent experiences (Abbott 1992 p. 438). Causality of events is even more complex if Henry R. Harrod's concept is taken into consideration, as this researcher perceives social facts rather in the network of co-relations and mutual, twosided relations, not necessarily of temporal nature (1956). Hence, the analysis of empirical data requires structural understanding of the relations between socialisation experiences and a given, adopted lifestyle. The methodical foundation for the selection and analysis refers to the attempt to establish networks, i.e. wider structures of events and their interpretation. According to Gavriel Salomon, cause and effect of social experiences evoke a network of relations (Salomon 1991), that are subsequently interpreted. Applying reconstruction of similarities and differences, the researcher searched for the genesis of a given code of conduct from the course of each event, despite the fact that correlations between the events are not always discernible and implicit. Hence, it is worth to ground own interpretation in a wider set of data, so the cause matrixes would not serve to interpret one case, but rather groups. Such approach enabled to launch the process of selecting experiences into those, that are repeatable and general, and on the other hand, distinguish these that are strictly individual, and of low event explanatory level. Because the matrixes were designed to determine common areas of experiences, the strategy of replication was applied in conformity with the assumptions. Analysis of the empirical material consisted of two stages, as during the first one a random group of 33 respondents was chosen and matrixes of the causes of pathological behaviours were designed. On the basis of the matrixes the second stage of data analysis allowed to apply the strategy of replication, i.e. the rest of the 67 respondents were subject to comparative analysis with regards to previously designed matrix patterns.

\section{Data Analysis}

One of the leading aspects of children's socialisation refers to their relations with adults, which forms a general perspective as it tackles the issue of direct and symbolic communication, embracing emotional relationships as well as common experiences during free time. The assessment of the quality of a child's relation with adults became a point of reference to select the source material and initial classification of the cases. During the interviews the respondents defined their subjective sense of relation with parents, describing contacts with their mother, father or/and sibling. For this purpose four classifying subgroups were introduced, linking respondents of similar experiences of relations with adults. On the basis of the experiences from childhood socialisation the following categories were established:
a. persons experiencing positive relations with their mother and father,
b. persons experiencing negative relations with their mother and father,
c. persons experiencing positive relations only with their mother,
d. persons experiencing positive relations only with their father. 
OF PSYCHOLOGY IN THE $21^{\text {st }}$ CENTURY Volume 7, 2013

72

At the first stage of the analysis of source material 33 randomly selected respondents were chosen and then divided in accordance with the below criteria (Table 1).

Table 1. The group of randomly selected respondents at the 1st stage of research analysis.

\begin{tabular}{|c|c|c|c|c|}
\hline $\begin{array}{l}\text { Relations with adults in t } \\
\text { childhood }\end{array}$ & & $\begin{array}{l}\text { Age when the first deviant behaviour } \\
\text { occurred }\end{array}$ & $\begin{array}{c}\text { Number } \\
\text { of people } \\
\text { in special } \\
\text { purpose } \\
\text { school and }\end{array}$ & $\begin{array}{l}\text { Number of people } \\
\text { in correctional } \\
\text { institutions }\end{array}$ \\
\hline $\begin{array}{l}\text { Positive relations with both } \\
\text { parents }\end{array}$ & 8 & $\begin{array}{l}12 \text { (2 persons) } \\
14,15,16 \text { ( } 2 \text { persons), } 17 \text { ( } 2 \text { persons) }\end{array}$ & 1 & 0 \\
\hline $\begin{array}{l}\text { Negative relations with } \\
\text { both parents }\end{array}$ & 22 & $\begin{array}{l}9,10 \text { ( } 2 \text { persons), } 12 \text { ( } 2 \text { persons), } 13 \text { ( } 3 \\
\text { persons), } 14,15 \text { ( } 4 \text { persons), } 16 \text { ( } 5 \text { persons), } \\
17 \text { ( } 4 \text { persons) }\end{array}$ & 5 & 2 \\
\hline $\begin{array}{l}\text { Good relations with the } \\
\text { mother }\end{array}$ & 2 & 15,16 & 0 & 0 \\
\hline $\begin{array}{l}\text { Good relations with the } \\
\text { father }\end{array}$ & 1 & 12 & 1 & 1 \\
\hline
\end{tabular}

Total $=33$ cases researched during the 1st stage of analysis

The following matrixes provide reconstruction of events and behaviours that make up a network of mutual influences. Each event remained in cause-effect relation combining behaviours, emotions and subjective approaches that altogether shaped the specific lifestyle. It has been so deeply rooted that the researched respondents still - as adults aged 22 to 30 - manifest criminogenic lifestyle, having committed criminal offences repeatedly and being deprived of their liberty already for few times.

The group experiencing positive relations with their mother and father during their childhood was divided into three subgroups. The differences occurred during the analysis of socialisation experiences and circumstances of the emergence of the first deviant behaviours, as socialisation process was accompanied by given events that launched the process of modification in current lifestyle, whereas acceptable behaviours were replaced by the deviant ones.

Differences in the interference of the socialisation process allowed to distinguish three matrix models presenting the process of consolidating criminogenic lifestyle (subgroup 1,2,3). The subgroup 1 presents similar experiences of three respondents as the reconstruction of their experience was related to palpable disturbances implying a sequence of harmful behaviours. For instance, their childhood was stigmatised by sudden death of the father (when the child was 12), parents' divorce and father's departure (when the child was 15), favouring elder sister by the parent degrading the son at the same time (when the boy was 15). The analysis of the process of pathogenesis revealed significant areas of common experiences for each of the respondents, as presented in the Figure 1. 


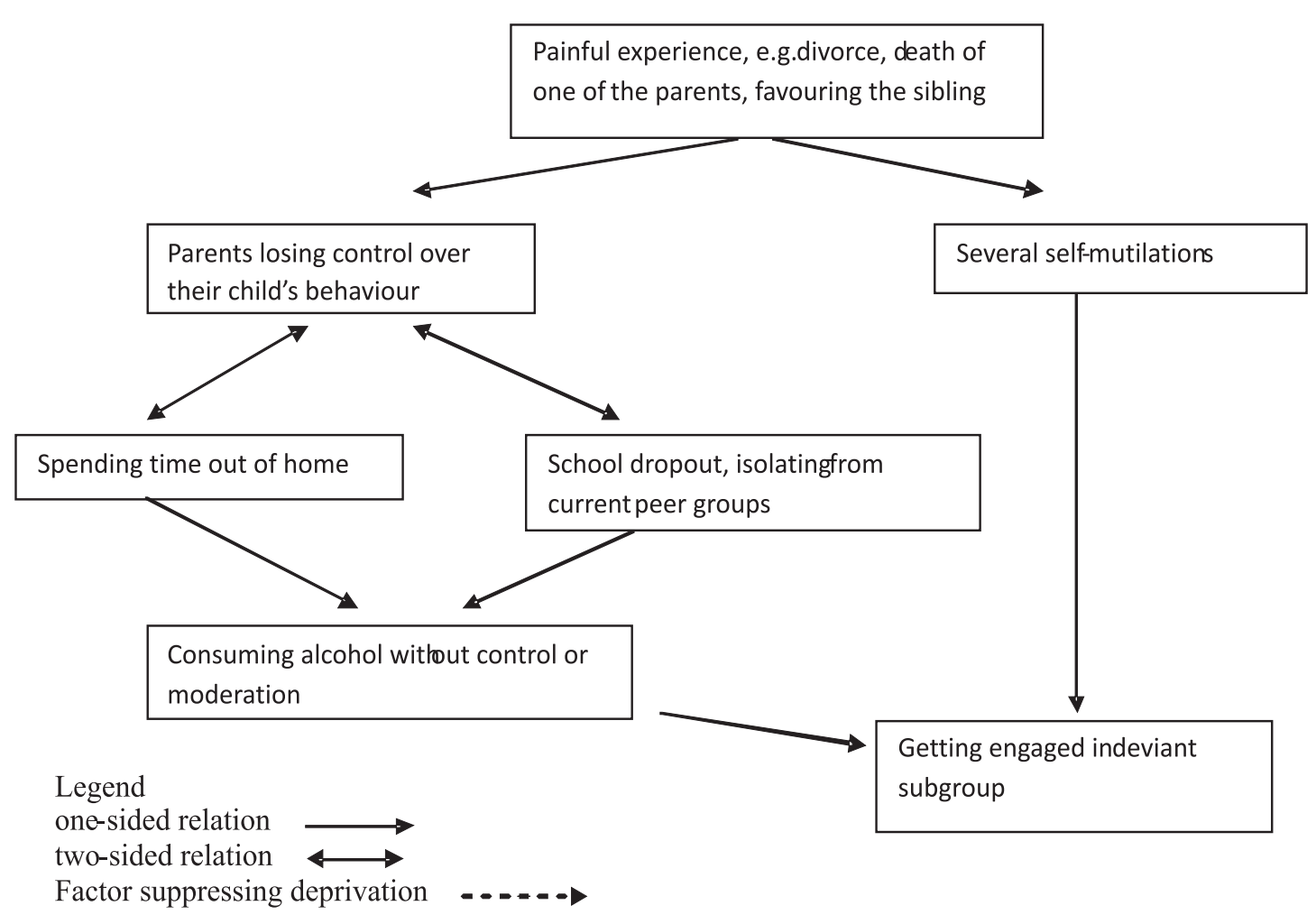

Figure 1: Course of consolidating criminogenic lifestyle (subgroup 1, 3 persons).

Distinguishing the second subgroup resulted from different socialisation experiences, causing disturbance within a socialisation process. The disturbances were neither of rapid nor emotionally painful character, compared to the case of subgroup 1, as their key role was rather played by the internal context related to the negative influence of deviant peer groups. Figure 2 presents the area of common experiences of these individuals. However, it is worth to notice that there were no factors suppressing nor stopping such pathogenic process. Socialisation in negative social circumstances provided a set of behavioural competencies that were easily duplicated in further deviant groups.

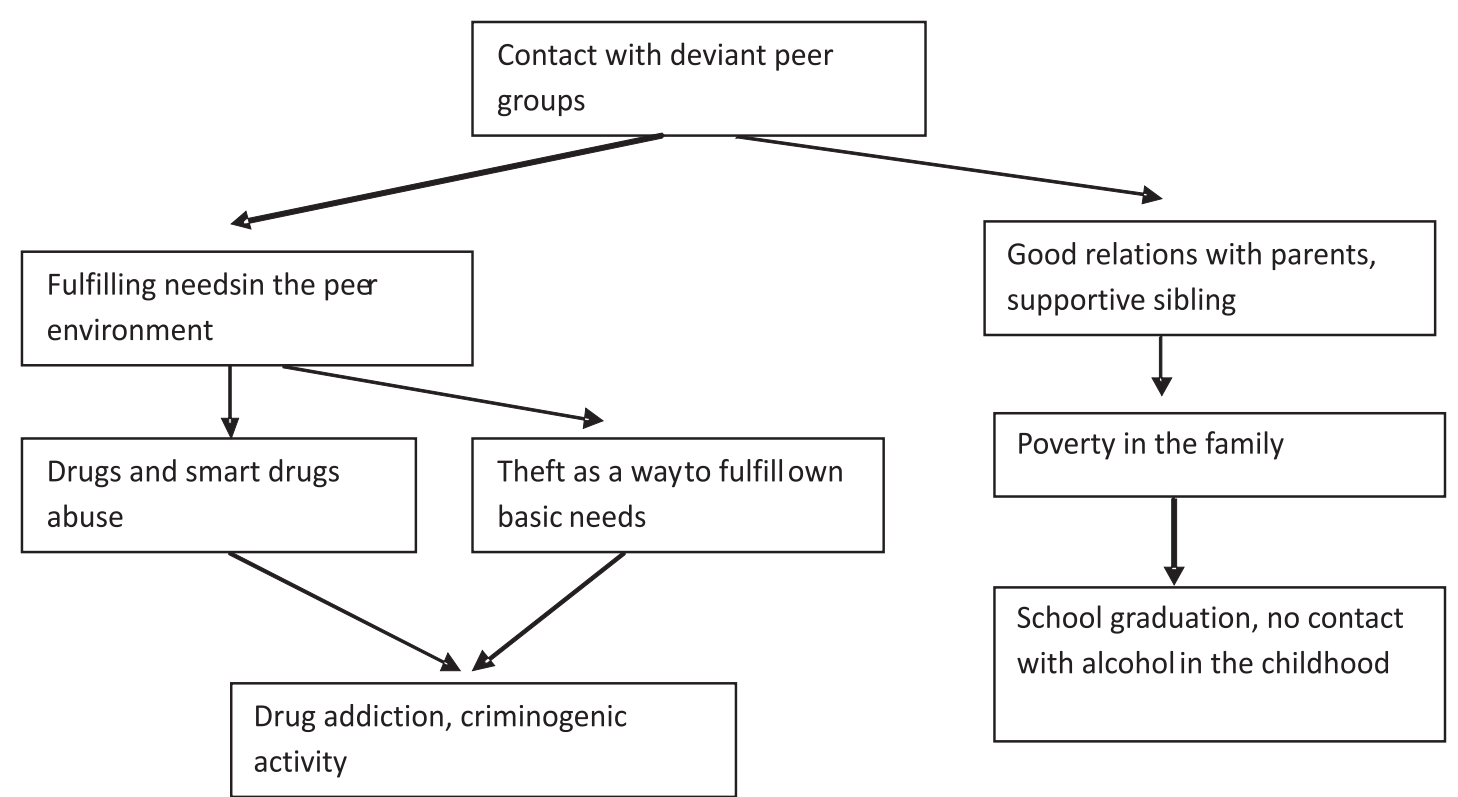

Figure 2: Course of consolidating criminogenic lifestyle (subgroup 2, 3 persons). 
OF PSYCHOLOGY IN THE $21^{\text {st }}$ CENTURY Volume 7, 2013

74

Figure 3 presents experiences of one respondent, nonetheless due to its specificity it is significant in terms of research objectives, as there is significant factor emerging, i.e. the primary process of social aberration that took place as early as at the age of 12 . On the other hand, the socialisation process was interfered due to the family eviction to a depraved environment. It is also noticeable that although the family was poor, there were no pathogenic behaviours manifested by the parents. Nonetheless, deprivation caused by the change of environment made both of this family's sons adopt criminogenic lifestyle and go to prison in their adult lives.

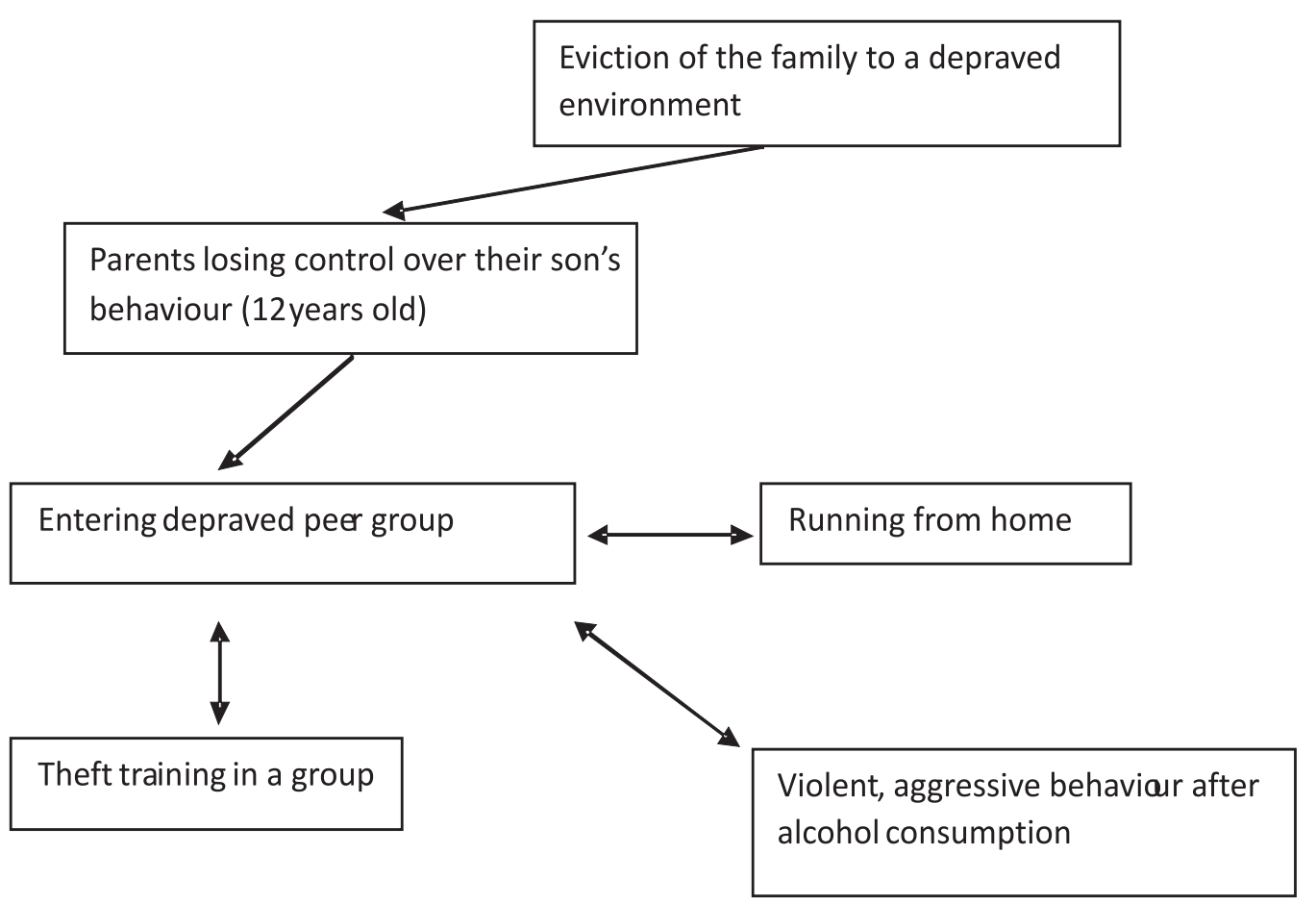

Figure 3: Course of consolidating criminogenic lifestyle (subgroup 3, 1 person).

Analysis of the pathogenesis of the respondents behaviour experiencing negative relations with their mother and father during their childhood $(\mathrm{N}=22)$

The number of respondents assessing their relations with parents during childhood as negative is definitely larger in the researched group. Parents (as well as the parent's cohabite) on one hand passed on negative patterns of functioning, and on the other manifested brutal behaviour towards own children. Hence negative experiences resulting from a wide catalogue of deviant behaviours among boys (Table 2). However, it is striking that only in five cases the family court located children in special purpose school and education centre in order to protect them from their parents. In two cases the children were placed in correctional institutions, yet it was the repercussion and consequent reaction to already consolidated deprivation. 
Table 2. Parents' (caretakers') deviant behaviour towards respondents in their childhood.

\begin{tabular}{|c|c|c|c|}
\hline & Mother & Father & Other factors: \\
\hline Parents alcoholism & 14 & 13 & $\begin{array}{l}\text { Prison experiences of the } \\
\text { sibling - } 8 \text { cases }\end{array}$ \\
\hline $\begin{array}{l}\text { Parental violence towards } \\
\text { own children }\end{array}$ & 2 & 7 & $\begin{array}{l}\text { Permanent contacts with } \\
\text { depraved criminal groups }-4 \\
\text { cases }\end{array}$ \\
\hline $\begin{array}{l}\text { Lack of parental interest in } \\
\text { their children's life }\end{array}$ & 3 & 5 & \\
\hline $\begin{array}{l}\text { Unfulfilled children's basic } \\
\text { needs, negligence }\end{array}$ & 6 & $\begin{array}{l}\text { (lack of data generally resulting } \\
\text { from assigning this role to the } \\
\text { mother not the father) }\end{array}$ & \\
\hline $\begin{array}{l}\text { Promiscuity, often change of } \\
\text { partners }\end{array}$ & 3 & 0 & \\
\hline Parental criminal liability & 1 & 2 & \\
\hline
\end{tabular}

During the reconstruction of the circumstances of the emergence of socialisation disturbances three causes-effect subsequent matrixes were outlined (subgroup 4, 5,6). Similarly as in the first group of respondents, each structure of an event was differentiated on the basis of the pathogenesis evolution.

The forth subgroup embraced those who located interference of their socialisation and emergence of pathogenesis within aborted relations with parents. Apart from the fact that the parents fulfilled their parental care insufficiently, additionally strong isolation of children occurred. In most cases it was manifested directly, e.g. parents getting divorced and abandoning children or isolating from them inexplicitly (taking no interest in their children's needs), as shown in Figure 4. This subgroup referred to the greatest number of persons, i.e. eleven, with the manifestation of their deviant behaviours of the age between 10 to 16 .

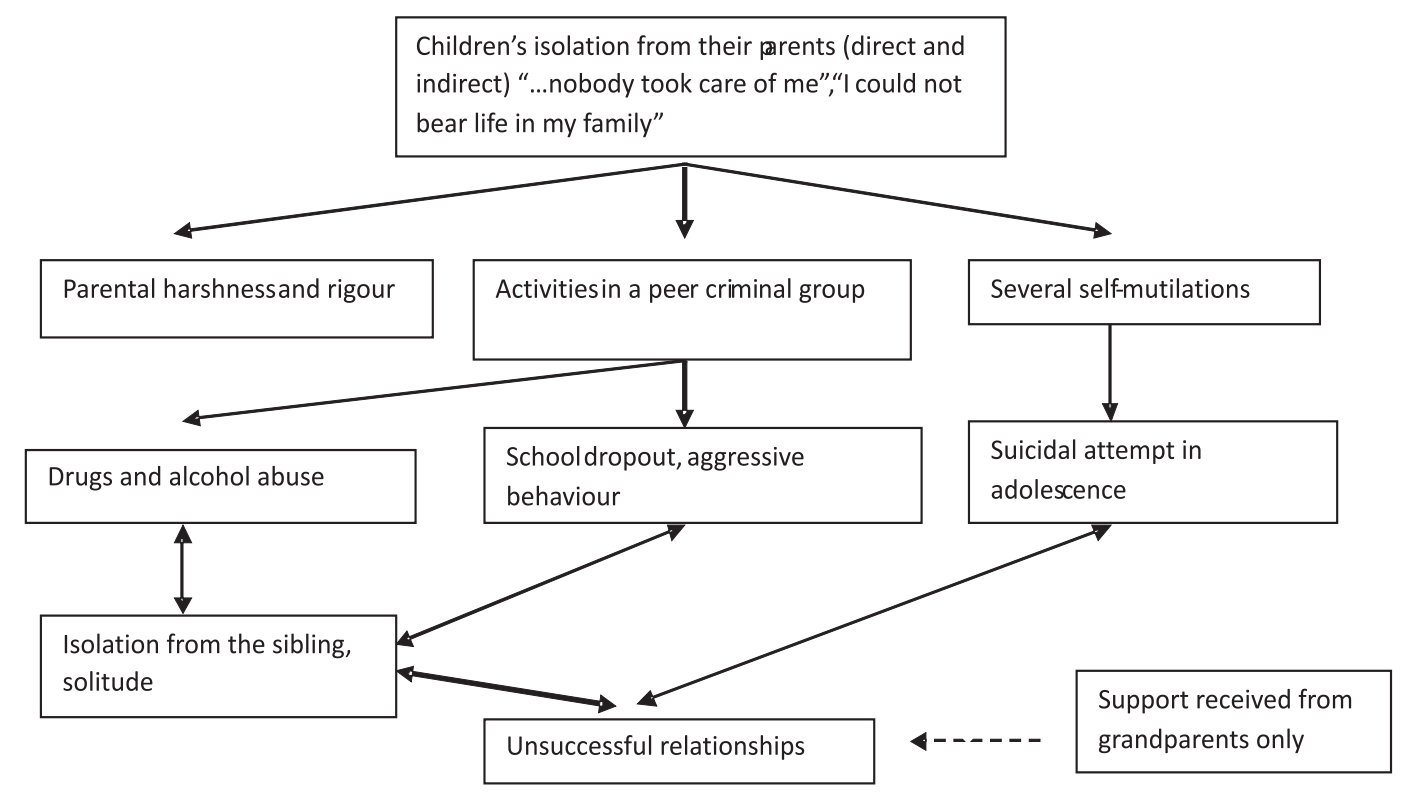


The fifth subgroup included those who perceived genesis of their criminogenic lifestyle through the experiences of the socialisation environment. They had contact with influential patterns of negative behaviours that were addressed by the peers and adults who identified themselves with criminogenic groups. At this point it is worth to recall the deterministic function of socialization experiences, as harmful conditions of social group and chronic impact of negative patterns of functioning in case of these respondents located them within marginal, deviant social group they gradually settled into.

Such experience was shared by nine persons with the emergence of influential deviant behaviour occurred between the age of 9 and 16 .

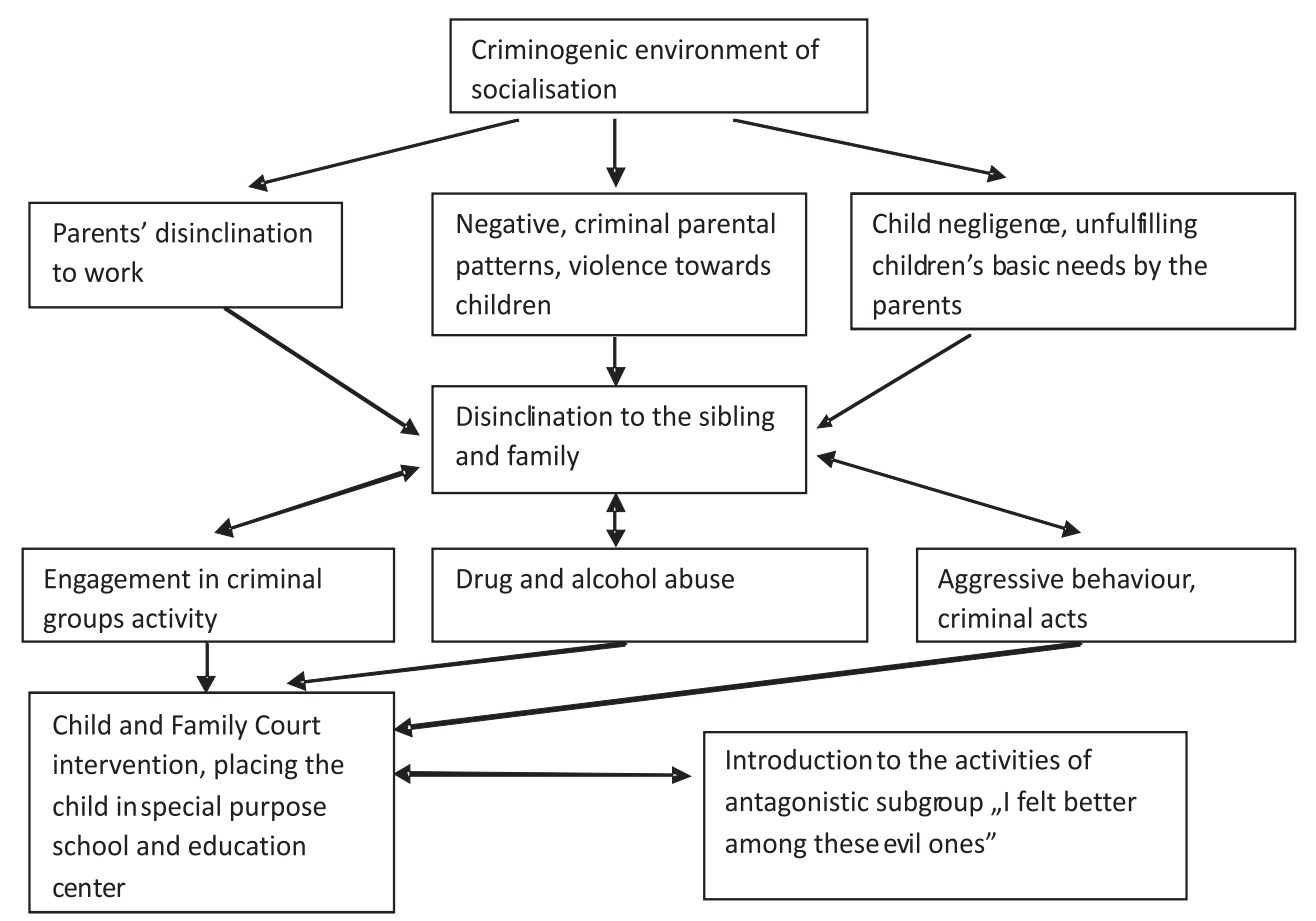

\section{Figure 5: Course of consolidating criminogenic lifestyle (subgroup 5, 9 persons).}

The sixth subgroup embraced two persons, whose manifestation of harmful behaviour occurred at the age of 17 and their experiences specifically combine rejection and isolation from their families with concurrent engagement in the activities of criminogenic groups (Figure 6). It is worth to emphasise that the below matrix depicts not only the structure of evens and experiences, but rather a kind of loop where events conditioned one another. For that purpose it is hindered to explicitly define which experience is the cause and which is the effect as they all influence each other both ways. 


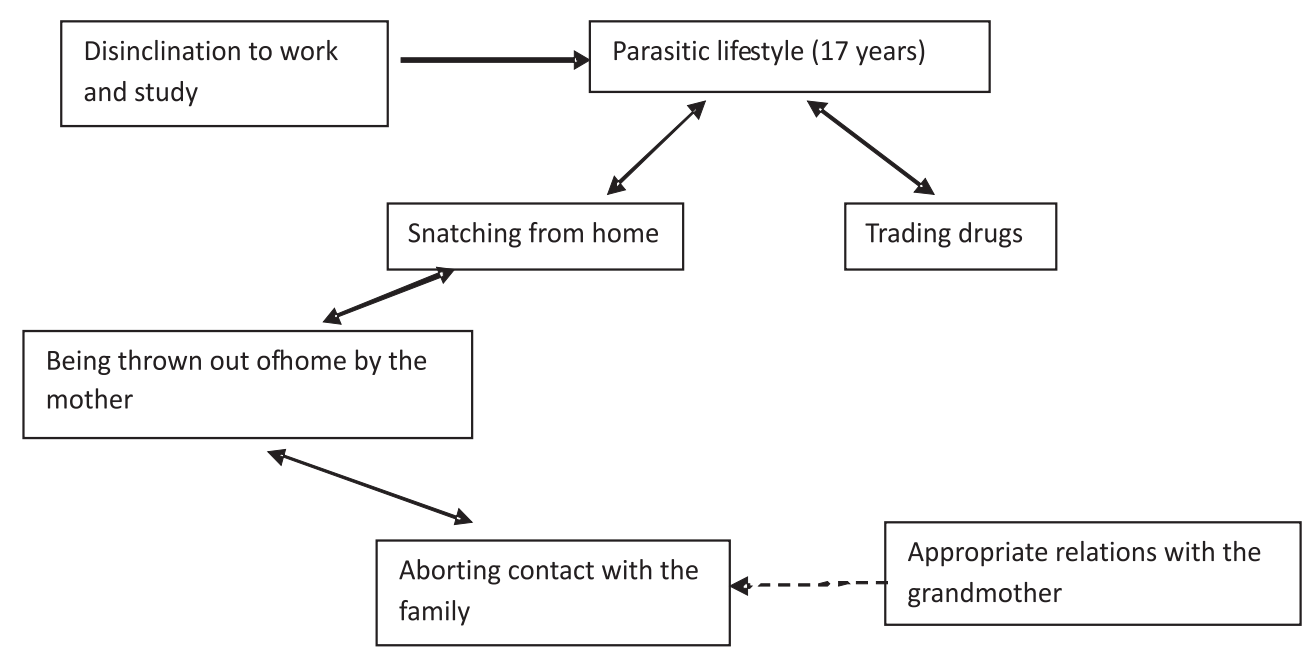

\section{Figure 6: Course of consolidating criminogenic lifestyle (subgroup 6, 2 persons).}

Analysis of the pathogenesis of the respondents behaviour experiencing positive relations with one of their parents during their childhood $(\mathrm{N}=3)$

Number of respondents that had positive relations only with one of the parents was smallest in the researched group. Good relations with mother were declared only in two cases, whereas with the father just in one case. Despite insignificant presentation of these one-side positive relation, qualitative research cannot neglect this problem, especially that criminology theories repeatedly recall mother's and father's role in shaping the lifestyle of their grown-up sons.

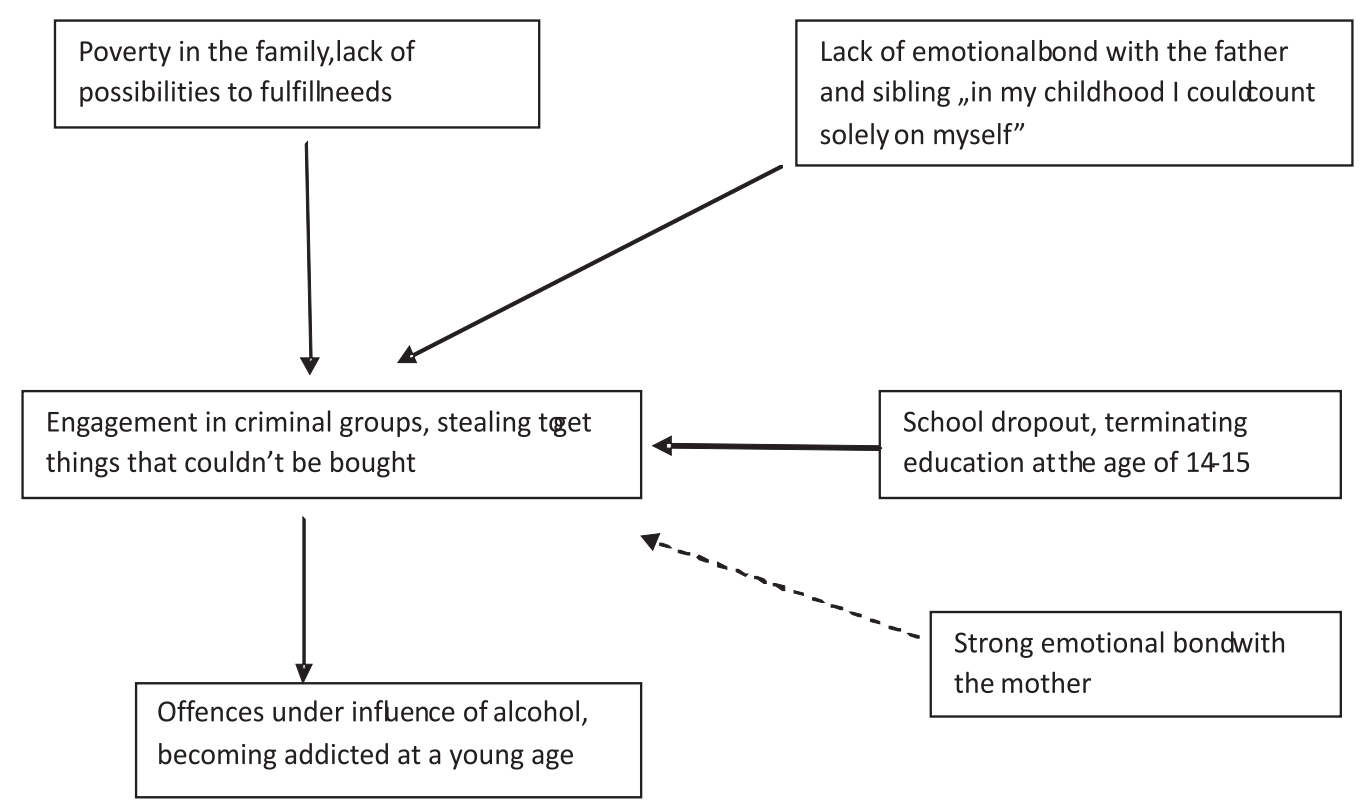

\section{Figure 7: Course of consolidating criminogenic lifestyle with positive relations with their mother only (subgroup 7, 2 persons).}

The key issue is the mother's position and her support as in both cases it was emphasised by the adult offenders. One of them got involved in the activity of criminogenic group, whereas the other became addicted to alcohol. Notwithstanding, both blamed their family for the fact that they were isolated and unaccepted, and in both cases their mother was the only person supporting them in their childhood. 
Last of the researched group consisted of only one respondent that shared strong bond solely with his father, what seems to be particularly interesting issue in researching men population. The mother did not participate in the boy's upbringing, as she was addicted to alcohol and abandoned the family. Hence his father brought him up and during this stage there were no socially harmful activities emerging. However, his father's suicidal death evoked strong auto-aggressive reaction of self-mutilation and suicidal attempts that resulted in psychiatric treatment. The process of pathogenesis began early, i.e. at the age of 12 , and the child was located in special purpose school and education center as he did not maintain relations with his mother nor further family. Hence, as early as in the period of childhood drug and alcohol abuse were intensified.

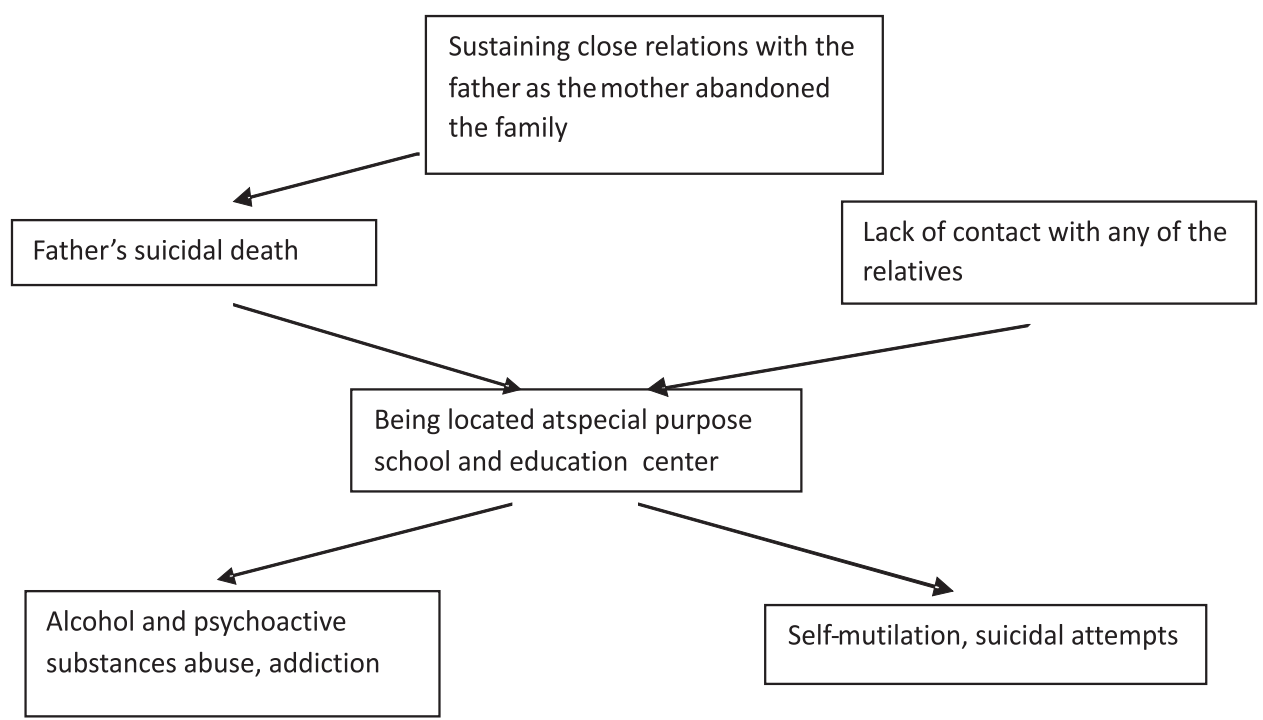

Figure 8: Course of consolidating criminogenic lifestyle with positive relations with their father only (subgroup 8, 1 person).

\section{Research Results}

Analysing the research results the deterministic nature of the course of socialisation is noticeable, and the matrixes depicting the lifestyle reflect two sequences of the course of socialisation.

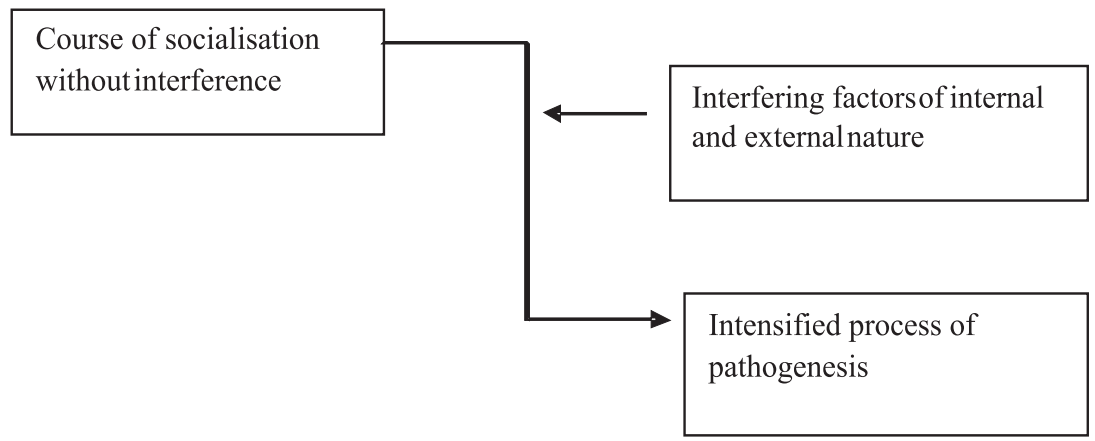

\section{Figure 9: First sequence of the course of the change in functioning style (Figures $1,2,3,8)$.}

Among the research cases factors interfering socialisation emerged between the age of 12 and 15 , what must be taken into account as it occurred when children did not posses developed mechanisms to deal with experiences and influences they were subject to. Moreover, they could not count on in-depth, social structure of support, nor had the competences to manage own fate or possibilities 
to search for new, alternative interpersonal relations. Confirmation of such thesis can be found in the catalogue of behaviours they manifested such as self-mutilation, suicidal attempts, dropping out Volume 7, 2013 school or excessive alcohol abuse. Already experienced activities were aborted by a strong personal trauma replacing the current structure of experiences. The dramatic and rapid intensification of such harmful behaviours as well as their categorical nature is worth highlighting in the context of the objectives of the research project. If the young men consumed alcohol, they did it intensively and with no limits. Similarly, they would not play truant, but quit school definitely. Additionally, their current peer environment would be entirely abandoned for the sake of contacts with deprived groups. Uncompromising termination of the current lifestyle is confirmed by the analysis of vocabulary used to describe these behaviours. It is a complex situation from the perspective of preventing deprivation, as the pedagogue's or school psychologist's activities can become in vain as change in the behaviour is so rapid and uncompromising that children do not seek for help nor assistance, also due to the fact that they do not want to return to their previous lifestyle.

There is also noticeable issue of relative deterministic power of the socialisation process, as current, positive course of socialisation (in particular appropriate relations with both parents) should create protective factors, that bind a person to given life environment. Criminogenic theories of social control pay great deal of attention to this aspect as solid relationships with the social surrounding crystallise during the course of socialisation. The respondents themselves describe their parents' attempts to protect them from social aberration in a specific manner, i.e.: "...parents told me a lot about misbehaviour, but I didn't care", “...they never had a reason to punish me", "childhood was good, but with discipline", "they cared for children". It therefore seems that their behaviours did not manifest a sporadic sign of rebellion or powerlessness, but became consolidated within criminogenic lifestyle that led them in their adolescence to transgression of the law.

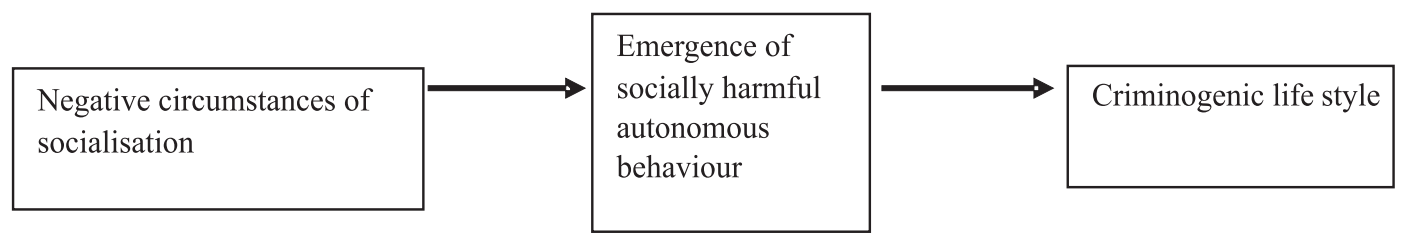

\section{Figure 10: Second sequence of the course of the change in functioning style (Figures 4,5,6,7).}

These cases confirm the deterministic function of socialisation in the childhood, as negative experiences of relations with parents and growing up in pathogenic environment equipped children with specific life dispositions. Many of the respondents explicitly stressed that colleagues, brothers or even fathers, taught them to steal, encouraged to start fights and hurt others. Thus, deprived group of criminals became a natural habitat for growing up and autonomous activity, as such groups established area of acceptance and allowed to fulfil own needs. It is worth to highlight that the catalogue of such needs was prosaic and concentrated mainly on material issues, i.e. wanting to have the things that others poses. Due to the fact that the family environment was not interested in fulfilling children's needs nor having resources for this purpose, the criminal peer group provided a natural opportunity for group fulfilment of such needs. At this point the thesis seems to reflect the findings from police statistics that the youth commit crimes most frequently in organised groups.

While analysing this issue it is crucial to focus on two dominant factors shaping negative socialisation of the researched respondents. On one hand it is the criminogenic life environment, and on the other - lack of acceptance from the relatives and closest family members. In the course of respondents' life, both factors appeared undoubtedly together as it is difficult to consider children's acceptance in a situation when their parents neglect them or manifest violent, brutal behaviour towards their offspring. However, from the perspective of pedagogical and psychological work with the prisoners, it is worth to notice that as adults these offenders realise the void of emotional contact with their relatives. Lack of fulfilment of such needs is not compensated in further stages of life. Moreover, none of the social groups they belonged to, and identified with, completed this gap. 
Such conclusions are significant for the resocialisation practices as it does not only prove its limited possibilities, but acknowledges that many of the recidivists do not become subject of emotional desensitisation as they realise such lack of emotional relations.

The attempt to locate unfulfilled needs from childhood is also one of the key issues in the discussion concerning the mechanisms of consolidating criminogenic lifestyle. The cause-effect matrixes revealed relations between unfulfilled needs and disturbed behaviours whereas in the case of younger children, the internal, negative emotional experiences were particularly traumatic. Situations such as the death of the relatives, abandoning the child or lack of child acceptance by parents or sibling jeopardise the needs of belonging, acceptance or sense of security. At large, such issues were experienced by the respondents in their early age, i.e. they occurred too early for them to posses tools and skills to deal with such traumas. Unfortunately, they were not supported by institutions established for such purpose. The behaviours of these children were significantly of internalised nature, aiming to withdraw from the activity, whereas self-mutilation, as well as alcohol and drug abuse were merely impulses for different authorities to place such children in different institutions, sometimes protecting their lives from death. Nonetheless, their experiences related to a destructive situation remained unnoticed as the intervention took place later, i.e. when the harmful activities have already emerged.

The depicted figures present the catalogue of external factors shaping criminogenic lifestyle. Lack of parents' engagement in fulfilling life needs of their children made the latter search for own ways to achieve what others had and possessed. For that purpose they used contacts with depraved peer groups, hence the lifestyle was shaped in depraved environment generating number of conflicts with law, but providing with desired material resources. The urge to possess was strong enough to prevail negative consequences of the punishment they were subject to for their offences. Nonetheless, it proved not to be deterrent enough. Such pressure to fulfil the need to posses was entirely accepted by those who had been neglected by their parents, as such parents would not undertake activities aiming to fulfil at least the basic needs. Thus they found themselves in a situation of intense, unfulfilled urge to posses, that determined their behaviour.

\section{Conclusions}

The worked-out cause-effect matrixes served as a tool to interpret socialisation experiences of the second group of respondents as well. The replication allowed to analyse the above issue within the framework of wider biographical experiences. The distinguished streams of common childhood experiences implied channels that grouped individual experiences, revealing similar context of the genesis of criminogenic lifestyle. Taking the above into consideration, the overall conclusions drawn from the research results can be formulated as follows.

1. From the perspective of prevention and supporting children in particularly difficult life situation it is worth to focus on the insignificant role played by factors suppressing the process of deprivation. The matrixes did not reveal powerful factors supporting socialisation of children nor factors suppressing or diverting the process of pathogenesis. Insignificant role of school, church or other social institutions participating in the process of socialisation are also among the issues worth considering. Moreover, during the period of strong, negative personal experiences the research persons were not provided with support, hence canalising the tension in self-mutilation and suicidal attempts.

2. The issue of influential power of socialisation experiences while consolidating given lifestyle is crucial, as children's positive experiences of relations with parents did not prevent further course of events and activities leading to criminogenic lifestyle (group 1 , subgroup 1,2,3). Traumatic personal experiences or the influence of peer environment were sufficient to take the edge over current habits, values and etc. Concurrently, the process of socialisation in unfavourable conditions was resistant to influences of other social environments, prevailing duplication of deviant lifestyle by the children (group 2 , subgroup 4,5,6). It is worth to continue research projects within this range as it may 
contribute to the recognition of the power of socialisation at given developmental age. The researched respondents might have been too young for the process of appropriate socialisation providing with tools of protection against deviant behaviours. Their learned mechanisms were not sufficiently internalised to function as internal protective factors. Another interesting issue is the necessity to carry out research concerning families as it may be concluded that despite declared, positive relations with parents and appropriate socialisation, there might have been other, hidden factors that favoured the rapid tendency to change the way of functioning.

3. Another key point is the issue of social costs of deprivation, as during the analysis of biographies there was a case when eviction of a family to deprived environment brought about engagement of two sons in deviant criminal groups and as a result, in their adulthood they became a repeated offenders. Eviction and change of living conditions emerged in Figure 3 as an initial factor generating further harmful activities. In Poland, as well as in other countries, they is a widely-discussed problem of evictions of impoverished families, that have become financially insufficient. Additionally, another problem is the social poverty ghettos that become the material reality of such families. Hence, it is worth to consider the real social costs of such actions, as if it is recognised that eviction and the process of ghettoisation are the predicators of criminogenic lifestyle, the financial costs of committed crimes and social costs of generating the criminal group are incomparably higher than the insufficiency of a family to maintain the house.

4. Reflection tackling unfulfilled needs of possession implies conclusions crucial in terms of practical application for psychology and penitentiary pedagogy. In many cases unfulfilled children's needs evoked concentration on activities aiming to posses and gather material values that others had at their disposal. In many cases such desire led to repeated punishment for theft. Hence, penitentiary tutors shall not neglect the issues of axiology, i.e. expanding the catalogue of values as well as the issue of social security. These are crucial aspects as the recidivists essentially do not posses, or possess insignificant competences to earn money and fulfill own possession needs. If they shall not learn to control it and do not expand the set of values crucial in life, it will be easy to foresee that they will return to their criminal activity in order to fulfill such need in only way they are familiar with.

\section{References}

Abbott, A. (1992). From causes to events: Notes on narrative positivism. Sociological Methods and Research, 20 (4), 428-455.

Achenbach, T. M., \& Edelbrock, C. S. (1984). Psychopathology of Childhood. Annual Review of Psychology, $35,227-256$.

Achenbach, T. M. (1991). Manual for the youth self-report and 1991 profile. Vermont: Burlington.

Barber, B., \& Olsen, J. E., \& Shagle, S. C. (1994). Associations between parental psychological and behavioral control and youth internalized and behaviors. Child Development, 65 (4), 1120-1136.

Bielecki, J. (1993). Der rechtsextreme Gewaltstater. Hamburg: Bosch und Rohring.

Garfinkel, H. (1956). Conditions of Successful Degradation Ceremonies. The American Journal of Sociology, $61,420-424$.

Gassin, R. (2003). Criminologie. Paris: Dalloz.

Hurrelmann, K. (1994). Struktura społeczna a rozwój osobowości. Poznań: Wydawnictwo UAM.

Harrod, R. (1956). Foundations of inductive logic. New York: Macmillan.

Jakobs, G. (1991). Strafrecht. Allgemeiner Teil. Die Grundlagen und die Zurechnungslehre. Berlin.

Kucharewicz, J. (2008). Psychologiczna analiza motywacji przestępstw popetnianych przez nieletnich. Rozprawa doktorska. Katowice: UŚ. 
82 Mayer, H. (1936). Das Strafrecht des Deutschen Volkes. Stuttgart.

Milles, M. B., \& Hubberman, A. M. (2000). Analiza danych jakościowych. Białystok: TransHumana.

Modrzewski, J. (2007). Socjalizacja i uczestnictwo społeczne. Studium socjopedagogiczne. Poznań: Wyd. UAM

Muncie, J. (2004). Youth and Crime. London: Sage Publications.

Olechnowicz, H. (1998). Wczesne zapobieganie agresywności i przestępczości młodocianych. Biuletyn Polskiego Towarzystwa Kryminologicznego, 7, 9-14.

Qi, C. H., \& Kaiser, A. P. (2003). Behaviour Problem of Preschool Children From Low-Income Families. Topics in Early Childhood, 23, 188-216. doi: 10.1177/02711214030230040201

Palmer, E. J. (2007). Criminal thinking. In: D. Carson (Ed.) Applying Psychology to Criminal Justice. West Sussex: Wiley and Sons.

Rothbaum F., \& Weisz, J. R. (1994). Parental Caregiving and child externalizing behaviour in nonclinical samples: a meta-analysis. Psychological Bulletin, 116 (1), 55-74.

Rübab, G. A., \& Marshall, S. K., \& Shapka J. D. (2010) A domain-specific approach to adolescent reporting of parental control. Journal of Adolescence, 33 (3), 355-366.

Rzeplińska, I. (2005). Obraz przestępczości nieletnich w Polsce, w badaniach kryminologicznych przed i po transformacji. Archiwum Kryminalistyki, XXVIII, 331-344.

Salomon, G. (1991). Transcending the qualitative-quantitative debate: The analytic and systemic approaches to educational research. Educational Researcher, 20 (6), 10-18.

Służba Więzienna (2010). Retrieved from, http://www.sw.gov.pl/pl/o-sluzbie-wieziennej/statystyka/

Stanik, M. J. (2007). Rodzaj popełnionych przestępstw a różnice osobowościowe ich sprawców. Archiwum Kryminalistyki, XXIX-XXX, 193-202.

Toroń, B. (2012). Zagrożeni i skazani na resocjalizację, Zielona Góra: Wyd. Uniwersytetu Zielonogórskiego.

Trivers, R. (1971). The Evolution of Reciprocal Altruism. Quarterly Review of Biology, 46 (1), 35-57.

Tyszkiewicz, L. (2008). Kryminogeneza i sposoby jej badania. Archiwum Kryminalistyki, XXIX-XXX, 215225.

Urban, B. (2000). Zaburzenia w zachowaniu i przestępczość młodzieży. Kraków, Wyd. UJ.

Ubóstwo w Polsce w 2012 r. (2012). Retrieved from, http://www.stat.gov.pl/cps/rde/xbcr/gus/WZ_ubostwo_w_ polsce_2012.pdf

Advised by Miroslawa Wawrzak-Chodaczek,

University of Wroclaw, Poland

Received: November 20, 2013

Accepted: December 02, 2013 